\title{
UF

\section{'Firecracker Red' Caladium - a University of Florida Cultivar for Sunny Landscapes and Large Containers 1}

Zhanao Deng and Brent K. Harbaugh ${ }^{2}$

Caladiums (Caladium xhortulanum Birdsey) are often forced in containers or planted in landscapes. More than $95 \%$ of the caladium tubers used throughout the world for container forcing and landscape planting are produced in south-central Florida (Lake Placid, Sebring, and Avon Park). Red fancy-leaved caladium cultivars are popular for containers and landscapes and represented $21 \%$ of the total production acreage in Florida (Deng et al., 2005). Two primary cultivars in the red fancy group are 'Frieda Hemple' and 'Postman Joyner'. Their leaves have intense red color, but their tuber production is poor and plants are susceptible to soilborne diseases. The UF/IFAS caladium breeding program, since its beginning in 1976, has aimed to develop new red-leaved cultivars with improved tuber production and plant performance (Wilfret, 1988). Toward this objective, 'Florida Cardinal' was developed and released in 1988 (Wilfret, 1988). 'Firecracker Red', a new release in 2005, produces large leaves with intense red color and performs well in sunny landscapes and large containers. It is also improved in tuber production over 'Frieda Hemple' and 'Postman Joyner'.

\section{Origin}

'Firecracker Red' was derived from a cross between two commercial cultivars 'Red Frill' and 'White Queen'. 'Red Frill' was selected as the female parent because of its bright red color, production of many leaves, and excellent sun tolerance; 'White Queen' was selected because of its large leaves and bright red vein color. Ancestry of 'Red Frill' and 'White Queen' is unknown.

\section{Description of Tuber and Leaf Characteristics}

Jumbo-sized tubers of 'Firecracker Red' are multi-segmented, usually bearing three dominant buds. Tuber surfaces are brown with the cortical area yellow to a darker yellow-orange.

Leaves are peltate, sagittate-cordate, with palmate-pinnate venation. The center veins are red and diffuse into a red-purple color toward the leaf edge. The upper surface has an irregular green margin, bordering the entire leaf except for the basal leaf sinus where it is grayed-purple. Interveinal areas are red in the leaf center diffusing into a grayed

1. This is document ENH1040, a publication of the Environmental Horticulture Department, Florida Cooperative Extension Service, UF/IFAS, University of Florida October 2006. Please visit the EDIS Website at http://edis.ifas.ufl.edu.

2. Zhanao Deng, assistant professor, and Brent K. Harbaugh, professor, Gulf Coast Research and Education Center, Florida Cooperative Extension Serivce, UF/IFAS, University of Florida, Gainesville 32611. Please visit the EDIS Website at http://edis.ifas.ufl.edu.

The Institute of Food and Agricultural Sciences (IFAS) is an Equal Opportunity Institution authorized to provide research, educational information and other services only to individuals and institutions that function with non-discrimination with respect to race, creed, color, religion, age, disability, sex, sexual orientation, marital status, national origin, political opinions or affiliations. U.S. Department of Agriculture, Cooperative Extension Service, University of Florida, IFAS, Florida A. \& M. University Cooperative Extension Program, and Boards of County Commissioners Cooperating. Larry Arrington, Dean 
purple toward the leaf margin. Petioles are streaked dark red-purple and light red-purple.

'Firecracker Red' plants grown for approximately 4 months in full sun in ground beds had an average height of 22 inches. Its leaves are similar in size to other red-leaved fancy cultivars, averaging 13 inches long and 9 inches wide. The largest leaf on plants grown in a $25 \%$ shaded greenhouse produced from an intact number one tuber in a 5-inch pot averaged 9 inches long and 7 inches wide 7 weeks after planting.

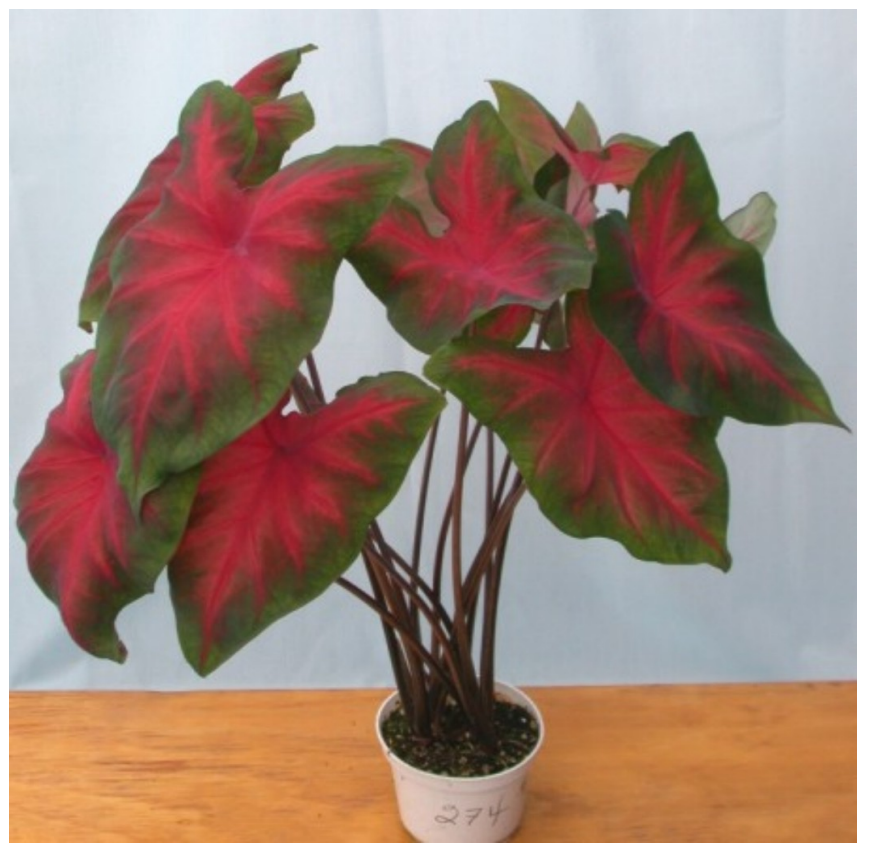

Figure 1. Caladium 'Firecracker Red' forced in a 4-inch-container using one No. 1 tuber. Credits: Univ. of Florida/IFAS Gulf Coast REC

\section{Tuber Production}

'Firecracker Red' was evaluated for tuber production and plant performance at University of Florida's Gulf Coast Research and Education Center-Bradenton, Fla., during 2003 and at Dover, Fla., in 2004. The soil in Bradenton was an EauGallie fine sand with about $1 \%$ organic matter and a $\mathrm{pH}$ of 6.2, and the soil in Dover was a Seffner fine sand with about $1 \%$ organic matter and a $\mathrm{pH}$ of 6.5 . Plants were grown in a plastic-mulched raised-bed system. The beds were 36 inches wide and 8 inches high with 1-inch caladium seed tuber pieces planted 6 inches apart in three rows (Bradenton) or 1-foot apart in two rows (Dover). Osmocote 18N-2.6P-10K 8- to 9-month controlled-release fertilizer was applied to the bed surface when shoot tips were emerging from the soil with $\mathrm{N}$ at 300 pounds per acre.

'Firecracker Red' tuber production was excellent with tuber weights nearly 1.5 times greater than that of 'Frieda Hemple' or 'Postman Joyner'.

'Firecracker Red' tuber weight exceeded all cultivars, except 'Florida Cardinal' in 2004, whose yield was similar. Similarly, the production index (an economic indicator of crop value) was highest for 'Firecracker Red' compared to all other cultivars, except 'Florida Cardinal', which had similarly high values. Although 'Firecracker Red' did not have the greatest number of marketable tubers, it ranked high compared to many other cultivars. Since it forms a "solid" tuber with few side tubers, it does not break apart into many small tubers during harvest. Tuber breakage is a problem with some other cultivars, e.g., 'Frieda Hemple'. The lack of breakage for 'Firecracker Red' is also evident in the high percentage of Mammoth, Jumbo and No. 1 tubers (95\% in 2003 and 84\% in 2004), ideal sizes for tubers sold for use in the landscape.

\section{Container Forcing}

'Firecracker Red' tubers were forced in 4 1/2-inch containers, and its growth parameters were compared to four red-fancy commercial cultivars. No. 1 tubers were planted in a peat/vermiculite mix (Vergro Container Mix A) on 24 June, 2002. The study was conducted in a glasshouse with 50\% light exclusion during the summer in Bradenton, Florida. Average daily temperatures ranged from a low of $70^{\circ} \mathrm{F}$ night to $85^{\circ} \mathrm{F}$ day during the experiment. 'Firecracker Red' had similar performance in pots compared to the other red-leaved cultivars tested or was essentially "average" with no significant differences for all measured parameters (plant height, number of leaves, and foliar characteristics). Thus, although 'Firecracker Red' has potential as a container plant, it appears to be better suited for use in the landscape.

\section{Landscape Performance}

Landscape performance of cultivars grown under full-sun conditions was evaluated in 2003 and 2004. Plant height, number of leaves, and foliar characteristics were recorded about 4 months after 
planting. 'Firecracker Red' had excellent overall

plant performance ratings for the first two rating periods (22 July, and 31 Aug.), and a lower, but good rating for 16 Nov. 'Firecracker Red' was the tallest cultivar evaluated in this test and, again, exhibited desirable landscape traits.

\section{Summary}

In summary, 'Firecracker Red' is intended for use in the landscape or large containers. It should perform well in full sun or partial shade conditions making it an ideal plant for the garden. Although extensive research and evaluations of this cultivar have been performed on small acreages, tuber producers are encouraged to plant only limited quantities of 'Firecracker Red' until they have gained experience in producing this cultivar. Standard postharvest treatment of tubers is recommended (Harbaugh and Tjia, 1985), and preplant hot-water treatment of tubers is encouraged to prolong their life.

\section{Availability}

A patent has been applied for for 'Firecracker Red' by the Florida Agricultural Experiment Station, and production of this cultivar is to be with a licensing agreement with the Florida Foundation Seed Producers, Inc., P.O. Box 309, Greenwood, FL 32443. Information on tuber availability and propagation agreements can be obtained from the Florida Foundation Seed Producers, Inc.

\section{Literature Cited}

Deng, Z. and B.K. Harbaugh. 2006. 'Dynamite Red' - A red fancy-leaved caladium for sunny landscapes and containers. HortScience 41:471-473.

Deng, Z., B.K. Harbaugh, R.K. Schoellhorn, and R.C. Andrew. 2005. 2003 Survey of the Florida caladium tuber production industry. UF/IFAS Extension Fact Sheet ENH 1007, 6 p. $<$ http://edis.ifas.ufl.edu/EP258>.

Harbaugh, B.K. and B.O. Tjia. 1985. Commercial forcing of caladiums. IFAS Univ. Fla. Agr. Ext. Serv. Circ. 621.
Wilfret, G.J. 1988. Florida Cardinal-A red caladium for forcing. Univ. Fla. Agr. Expt. Sta. Circ. S-351. 
Table 1. Perforamnce of plants grown from 1-inch tuber propagules in ground beds under full sun.

\begin{tabular}{|c|c|c|c|c|c|c|c|}
\hline \multirow[b]{3}{*}{ Cultivar } & \multirow{3}{*}{$\begin{array}{l}\text { Plant } \\
\text { height }^{2} \\
\text { (inch) }\end{array}$} & \multirow{3}{*}{$\begin{array}{l}\text { Leaves }^{z} \\
\text { (number) }\end{array}$} & \multicolumn{2}{|c|}{ Leaf $^{2}$} & & & \\
\hline & & & \multirow{2}{*}{$\begin{array}{l}\text { Length } \\
\text { (inch) }\end{array}$} & \multirow{2}{*}{$\begin{array}{l}\text { Width } \\
\text { (inch) }\end{array}$} & \multicolumn{3}{|c|}{ Overall plant performance ${ }^{y}$} \\
\hline & & & & & Early & Middle & Late \\
\hline Florida Cardinal & 18.5 & 16 & 11.8 & 7.5 & 3.7 & 4.1 & 4.3 \\
\hline Firecracker Red & 22.0 & 13 & 12.6 & 8.7 & 5.0 & 4.6 & 3.8 \\
\hline Frieda Hemple & 19.7 & 21 & 12.2 & 7.9 & 2.7 & 4.3 & 4.3 \\
\hline Postman Joyner & 15.4 & 13 & 11.4 & 7.1 & 2.5 & 2.7 & 3.7 \\
\hline Red Flash & 17.3 & 12 & 13.4 & 7.9 & 3.2 & 4.0 & 4.0 \\
\hline $\operatorname{LSD}(a=0.05)$ & 3.1 & 3.3 & 1.1 & 0.7 & 0.8 & 0.5 & 0.6 \\
\hline \multicolumn{8}{|c|}{$\begin{array}{l}{ }^{z} \text { Values presented are means of three replications with three plants measured per plot per year, averaged over } 2 \\
\text { years (2003 and 2004). } \\
\text { y Overall plant performance was rated July } 22 \text { (early), August } 31 \text { (mid), and November } 16 \text { (late), } 2004 .\end{array}$} \\
\hline
\end{tabular}




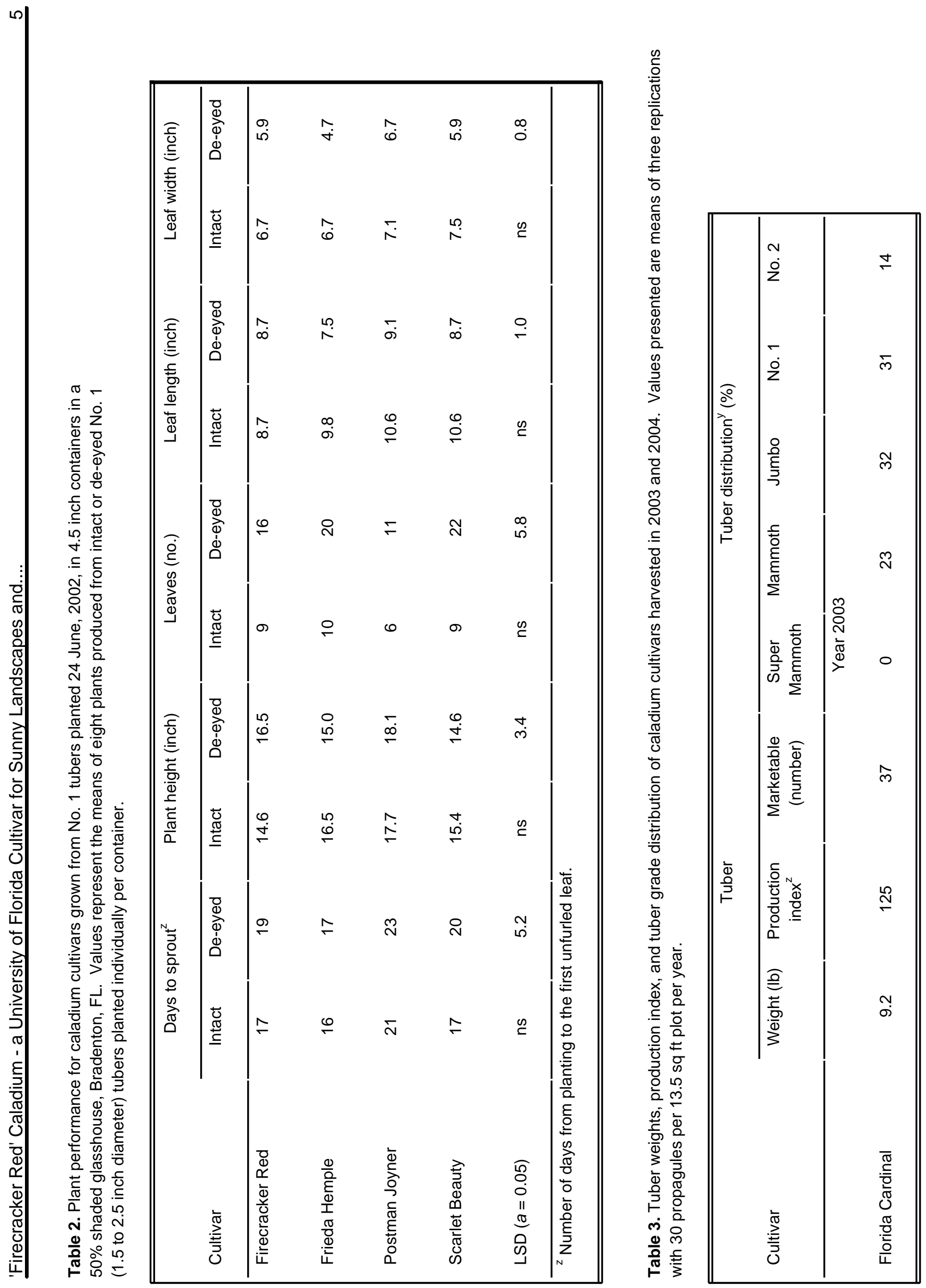




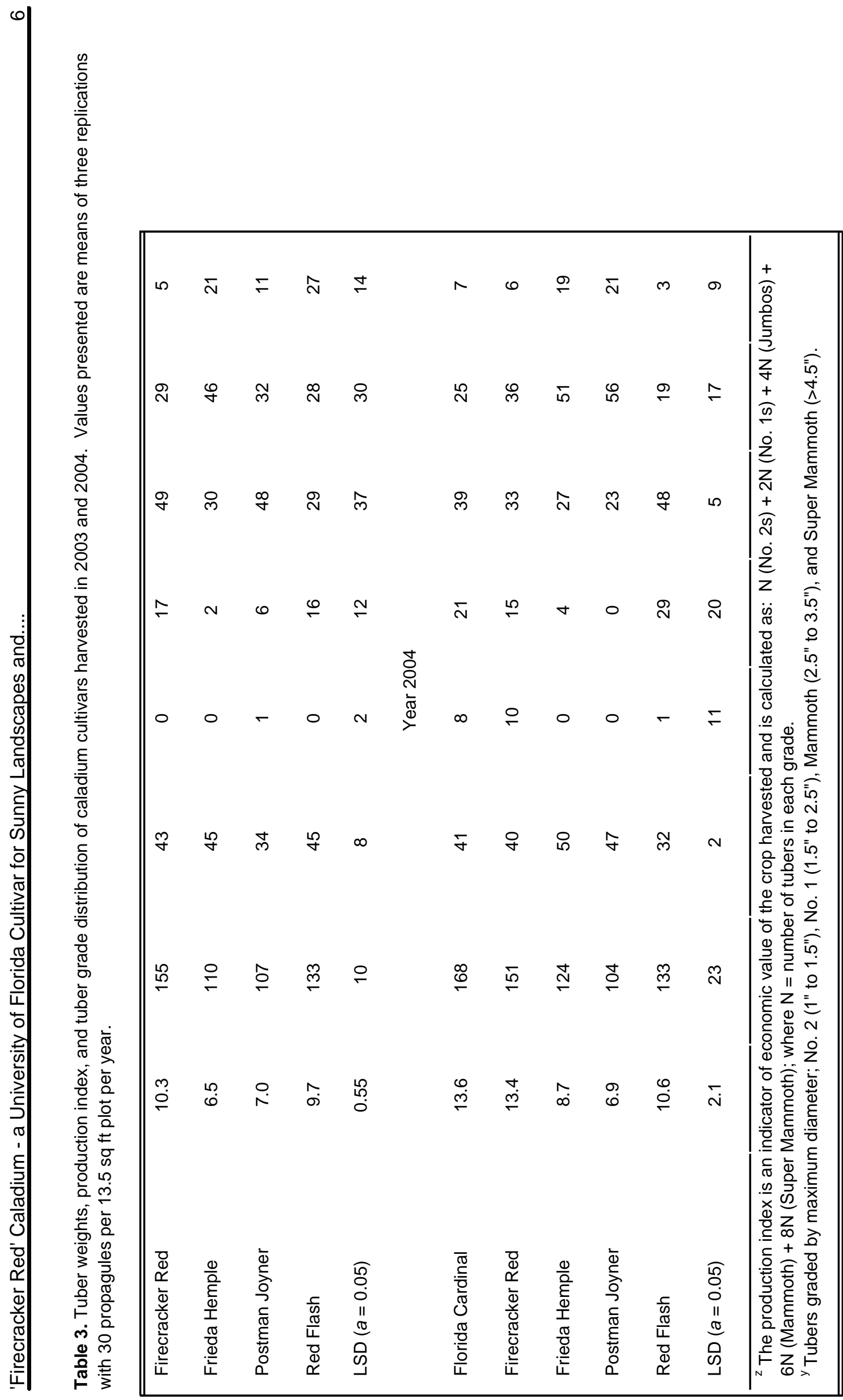

